\title{
Effect of rootstocks on tree size and yield of six Valencia orange clones ${ }^{1}$
}

\author{
Arturo Cedeño-Maldonado², Agripino Pérez-López, \\ Elvin Boneta ${ }^{4}$ and Carlos d. Torres
}

\begin{abstract}
Experiments were conducted at Adjuntas substation in the central mountain region of Puerto Rico to determine the effect of four rootstocks on growth and fruit production parameters of six clones of Valencia orange. Concerning fruit characteristics, the most notable differences among clones were in size, but also statistical differences were found in peel percentage and number of seeds per fruit. Significant differences in juice characteristics among clones were also found. Fruit production was superior for all four clones with Cleopatra mandarin as rootstock. There was significant difference between clones 3164 and 3264 concerning fruit production. There were no significant differences in yield efficiency during the first crop year; however, trees on Cleopatra mandarin and sour orange rootstocks were significantly taller, wider and had larger canopy volumes. Significant differences among different clones within particular rootstocks were found for tree height, tree width, canopy volume, fruit production and yield efficiency.
\end{abstract}

\section{RESUMEN}

Patrones de cítricas y tamaño del árbol y rendimiento de seis clones de Valencia.

Se realizaron experimentos en la Estación Experimental en Adjuntas, en la zona central montañosa de Puerto Rico, para determinar el efecto de cuatro patrones sobre el crecimiento y la producción de seis clones de china Valencia. Se constataron diferencias notables entre clones en cuanto al tamaño de las frutas, pero también se observaron diferencias significativas en cuanto a porcentaje de cáscara, número de semillas por fruta y caracteristicas del jugo. Se obtuvo una mayor producción en todos los clones cuando se usó la mandarina Cleopatra como patrón. Hubo diferencia significativa entre los clones $\mathbf{3 1 6 4}$ y 3264 en cuanto a producción total de frutas. No hubo diferencias significativas en eficiencia de rendimiento durante el primer año de cosecha informado, pero los patrones mandarina Cleopatra y naranja agria produjeron árboles más altos y con mayor volumen de copa. Se encontraron diferencias significativas entre clones para patrones especificos en cuanto a altura, amplitud y volumen de copa, producción total de frutas y rendimiento.

'Manuscript submitted to Editorial Board 15 October 1990.

Professor and Plant Physiologist, Department of Horticulture.

${ }^{3}$ Horticulturist (Retired), Department of Horticulture.

'Associate Horticulturist (Retired), Department of Horticulture. 


\section{INTRODUCTION}

The production of oranges in Puerto Rico has leveled to around 150 million fruits per year during the past decade. Imports of fresh orange fruits nearly doubled during that period. During 1987-88 a total of 154 million fruits were produced whereas approximately 16.5 million fruits were imported from the United States and other areas (3). Thus, there is an opportunity for increasing production of oranges for the fresh market.

Very few studies on citrus have been reported in Puerto Rico during the past decade and only one addressed problems related to production of oranges (5). The influence of rootstocks on production and quality of citrus fruits is well documented $(1,4,7)$. However, most studies have been conducted with plant materials and under soil and climatic conditions differing from those prevailing in the tropics. Further studies on the effects of rootstocks on yield and fruit quality of orange fruits under specific soil and climatic conditions in Puerto Rico are needed in order to verify existing data and generate new information.

The objective of this study was to determine the effect of different rootstocks on growth and fruit production of selected Valencia orange clones.

\section{MATERIALS AND METHODS}

The experiment was established at the Adjuntas Experiment Station in 1975. A factorial experimental design was used with six different clones and four rootstocks as main factors. There were four blocks of 48 trees with two trees for each treatment per replication, accounting for a total of 192 trees in the whole experiment. Planting distance was $7 \times 7$ meters with border trees surrounding the experiment. The soil was an Alonso clay (oxidic, isohyperthermic Typic Haplohumults). Annual precipitation in the area is around $1700 \mathrm{~mm}$ per year. Trees were not irrigated. Fertilizer application and other management practices followed recommendations of the Agricultural Experiment Station (2).

Data collection began 3 years after planting and included growth and fruit variables such as tree height, width and volume of canopy as well as number and weight of fruits and their juice content. Canopy volume was determined with the formula proposed by Wutscher and Shull (6). Most of the data herein reported were collected during crop years 1984-85 and 1985-86, when trees were 10 and 11 years old, respectively. Fruit and juice characteristics were determined from ten and five fruits per replication, respectively, selected at random during three 
consecutive crop years beginning in 1983. Canopy volume and yield efficiency calculations are based on data collected in December 1985.

\section{RESULTS AND DISCUSSION}

Table 1 presents fruit characteristics of the six clones under study. Data represent the average obtained during three consecutive crop years from 1983 to 1985 . Average fruit weight ranged from 168 to 291 grams. Clone 3264 produced significantly heavier fruits, whereas clones 2864 and 3664 produced the smallest fruits. Clone 3264 also had the greatest peel percentage while clones 2864 and 3664 had the smallest. All clones were almost seedless but clone 3264 approached complete seedlessness. All clones exceeded $47 \%$ juice content. Titrable acidity varied among clones. Clone 4064 had significantly lower percentage of titrable acid than clones 2864 and 3664 . Juice $\mathrm{pH}$ varied from 3.5 to 3.7. Brix to acid ratio was similar in all clones except in clone 3264 , which had a significantly lower ratio. According to table 1 , it is difficult to pinpoint superiority among the clones. Clone 3264, for example, had the largest fruit size but was very low in juice content.

Table 2 presents data on tree and fruit characteristics of the clones. There were statistical differences among some clones for tree height, canopy width and average production. Table 3 presents average fruit production per tree for crop years 1985 and 1986. Means for the six Valencia clones ranged from 170 to 228 fruits per tree. These figures are comparable to those reported by Pérez and Torres (5) for navel oranges. There were significant differences only between clones 3064 and 3264 . Rootstock effect was significant; Cleopatra mandarin was superior to all others.

TABLE 1.-Fruit characteristics of Valencia orange clones.

\begin{tabular}{cccccccccc}
\hline & $\begin{array}{c}\text { Fruit } \\
\text { weight } \\
\mathrm{g}\end{array}$ & $\begin{array}{c}\text { Peel/ } \\
\text { fruit } \\
\%\end{array}$ & $\begin{array}{c}\text { Seeds/ } \\
\text { fruit }\end{array}$ & $\begin{array}{c}\text { Juice } \\
\text { percent } \\
\text { age }\end{array}$ & $\begin{array}{c}\text { Titrable } \\
\text { acidity } \\
\%\end{array}$ & Brix & $\mathrm{pH}$ & $\begin{array}{c}\text { Brix/ } \\
\text { acid } \\
\text { ratio }\end{array}$ \\
\hline 2864 & $168 \mathrm{c}$ & $37.8 \mathrm{~b}$ & $5 \mathrm{a}$ & $52 \mathrm{ab}$ & $0.91 \mathrm{a}$ & $14.5 \mathrm{a}$ & $3.57 \mathrm{ab}$ & $16.1 \mathrm{ab}$ \\
3064 & $259 \mathrm{~b}$ & $40.3 \mathrm{~b}$ & $4 \mathrm{ab}$ & $51 \mathrm{ab}$ & $0.81 \mathrm{ab}$ & $12.5 \mathrm{ab}$ & $3.70 \mathrm{a}$ & $15.4 \mathrm{ab}$ \\
3164 & $254 \mathrm{~b}$ & $40.0 \mathrm{~b}$ & $3 \mathrm{~b}$ & $52 \mathrm{ab}$ & $0.82 \mathrm{ab}$ & $13.2 \mathrm{ab}$ & $3.51 \mathrm{c}$ & $16.0 \mathrm{ab}$ \\
3264 & $291 \mathrm{a}$ & $45.3 \mathrm{a}$ & $1 \mathrm{c}$ & $47 \mathrm{~b}$ & $0.83 \mathrm{ab}$ & $11.2 \mathrm{~b}$ & $3.62 \mathrm{ab}$ & $13.3 \mathrm{c}$ \\
3664 & $195 \mathrm{c}$ & $37.2 \mathrm{c}$ & $4 \mathrm{ab}$ & $57 \mathrm{a}$ & $0.87 \mathrm{a}$ & $14.2 \mathrm{a}$ & $3.65 \mathrm{ab}$ & $16.3 \mathrm{ab}$ \\
4064 & $236 \mathrm{~b}$ & $42.3 \mathrm{~b}$ & $5 \mathrm{a}$ & $50 \mathrm{ab}$ & $0.78 \mathrm{~b}$ & $13.2 \mathrm{ab}$ & $3.61 \mathrm{~b}$ & $17.1 \mathrm{a}$ \\
\hline
\end{tabular}

Values in columns followed by the same letter do not differ significantly at the 0.05 level according to Duncan's multiple range test. 
TAbLE 2.-Tree and production characteristics of Valencia orange clones'.

\begin{tabular}{cccccc}
\hline Clone & $\begin{array}{c}\text { Height } \\
\text { (meters) }\end{array}$ & $\begin{array}{c}\text { Width } \\
\text { (meters) }\end{array}$ & $\begin{array}{c}\text { Canopy } \\
\text { volume } \\
\text { (cubic meters) }\end{array}$ & $\begin{array}{c}\text { Average } \\
\text { production } \\
\text { (fruits/acre) }\end{array}$ & $\begin{array}{c}\text { Yield } \\
\text { efficiency } \\
\text { (fruits/m } \\
\text { canopy) }\end{array}$ \\
\hline 2864 & $2.52 \mathrm{abc}^{2}$ & $2.68 \mathrm{~b}$ & $5.19 \mathrm{a}$ & $175 \mathrm{ab}$ & $35 \mathrm{a}$ \\
3064 & $2.76 \mathrm{a}$ & $2.98 \mathrm{ab}$ & $6.29 \mathrm{a}$ & $170 \mathrm{~b}$ & $30 \mathrm{a}$ \\
3164 & $2.52 \mathrm{abc}$ & $2.92 \mathrm{ab}$ & $5.75 \mathrm{a}$ & $182 \mathrm{ab}$ & $33 \mathrm{a}$ \\
3264 & $2.67 \mathrm{ab}$ & $3.08 \mathrm{a}$ & $6.30 \mathrm{a}$ & $228 \mathrm{a}$ & $34 \mathrm{a}$ \\
3464 & $2.29 \mathrm{c}$ & $2.87 \mathrm{ab}$ & $5.43 \mathrm{a}$ & $197 \mathrm{ab}$ & $35 \mathrm{a}$ \\
4064 & $2.46 \mathrm{bc}$ & $2.88 \mathrm{ab}$ & $5.59 \mathrm{a}$ & $203 \mathrm{ab}$ & $36 \mathrm{a}$ \\
\hline
\end{tabular}

'Average value of the sum of data for all rootstocks for each characteristic.

"Values in the columns followed by the same letter do not differ significantly at the 0.05 level according to Duncan's multiple range test.

Table 4 presents data on tree size and yield efficiency parameters for the different rootstocks. There were no significant differences in yield efficiency for the 1985 crop. Cleopatra and sour orange, however, were superior to pummelo and sweet orange in 1986. Pummelo hybrid showed the lowest yield efficiency. Yield efficiency was much higher than that reported by Pérez and Torres (5) for Navel orange grafted on native sweet orange. Fruit production per tree was significantly higher for Cleopatra during both crop years. Trees grafted on Cleopatra were

TABLs: 3.-Average fruit production per tree for 1985 and 1986 crop years of six clones of late Valencia orange on four different rootstocks.

\begin{tabular}{|c|c|c|c|c|c|}
\hline \multicolumn{6}{|c|}{ ROOTSTOCKS } \\
\hline Clone & $\begin{array}{l}\text { Cleopatra } \\
\text { mandarin }\end{array}$ & $\begin{array}{l}\text { Sour } \\
\text { orange }\end{array}$ & $\begin{array}{l}\text { Pummelo } \\
\text { hybrid }\end{array}$ & $\begin{array}{l}\text { Sweet } \\
\text { orange }\end{array}$ & $\begin{array}{c}\text { Total } \\
\text { average }\end{array}$ \\
\hline 2864 & $277 \mathrm{ab}$ & $128 \mathrm{a}$ & $141 \mathrm{a}$ & $152 \mathrm{a}$ & $175 \mathrm{ab}$ \\
\hline 3064 & $262 \mathrm{ab}$ & $114 \mathrm{a}$ & $177 \mathrm{a}$ & $128 \mathrm{a}$ & $170 \mathrm{~b}$ \\
\hline 3164 & $243 \mathrm{~b}$ & 147 a & $157 a$ & $180 a$ & $182 \mathrm{ab}$ \\
\hline 3264 & $372 a$ & $150 \mathrm{a}$ & $195 a$ & 195 a & $228 a$ \\
\hline 3464 & $344 \mathrm{ab}$ & $133 \mathrm{a}$ & $155 a$ & $156 a$ & $197 \mathrm{ab}$ \\
\hline 4064 & $310 \mathrm{ab}$ & $218 a$ & $104 a$ & $174 \mathrm{a}$ & $203 a b$ \\
\hline $\begin{array}{c}\text { Total } \\
\text { average }\end{array}$ & $303 a$ & $148 \mathrm{~b}$ & $155 \mathrm{~b}$ & $164 \mathrm{~b}$ & \\
\hline
\end{tabular}

Values in the columns and the average row, followed by the same letter do not differ significantly at the 0.05 level according to Duncan's multiple range test. 
TABLE 4.-Effect of rootstock on tree size parameters and yield of late Valencia orange'.

\begin{tabular}{lcccc}
\hline & \multicolumn{4}{c}{ Rootstocks } \\
\cline { 2 - 5 } Characteristics & $\begin{array}{c}\text { Cleopatra } \\
\text { mandarin }\end{array}$ & $\begin{array}{c}\text { Sour } \\
\text { orange }\end{array}$ & $\begin{array}{c}\text { Pummelo } \\
\text { hybrid }\end{array}$ & $\begin{array}{c}\text { Sweet } \\
\text { orange }\end{array}$ \\
\hline $\begin{array}{l}\text { Yield efficiency } \\
\text { Yield efficiency }\end{array}$ & $40.98 \mathrm{a}^{\prime}$ & $42.21 \mathrm{a}$ & $36.10 \mathrm{a}$ & $36.38 \mathrm{a}$ \\
1986 & $40.19 \mathrm{a}$ & $32.31 \mathrm{ab}$ & $22.85 \mathrm{c}$ & $23.65 \mathrm{bc}$ \\
Fruits per tree, 1985 & $345 \mathrm{a}$ & $170 \mathrm{~b}$ & $193 \mathrm{~b}$ & $199 \mathrm{~b}$ \\
Fruits per tree, 1986 & $261 \mathrm{a}$ & $127 \mathrm{~b}$ & $117 \mathrm{~b}$ & $130 \mathrm{~b}$ \\
Fruits per tree, ave. & $303 \mathrm{a}$ & $148 \mathrm{~b}$ & $155 \mathrm{~b}$ & $164 \mathrm{~b}$ \\
Tree height & $2.90 \mathrm{a}$ & $2.28 \mathrm{c}$ & $2.40 \mathrm{bc}$ & $2.57 \mathrm{~b}$ \\
Tree width & $3.33 \mathrm{~b}$ & $2.62 \mathrm{~b}$ & $2.82 \mathrm{~b}$ & $2.82 \mathrm{~b}$ \\
Canopy volume & $7.92 \mathrm{a}$ & $4.20 \mathrm{c}$ & $5.52 \mathrm{~b}$ & $5.40 \mathrm{bc}$ \\
\hline
\end{tabular}

Data represent the average of the values obtained for the six different clones under study.

Values in rows followed by the same letter do not differ significantly at the 0.05 level according to Duncan's multiple range test.

also significantly taller and had a significantly larger canopy volume. Sweet orange and pummelo hybrid were very similar in terms of tree size parameters.

Significant differences for tree height and canopy width and volume among different Valencia clones within a particular rootstock were found only with the pummelo hybrid rootstock; for fruit production per tree in 1986, with Cleopatra mandarin and sour orange as rootstocks; and for yield efficiency, with sour orange and Cleopatra rootstocks in 1985 and 1986 crop years, respectively (tables 5 and 6). Significant dif-

TABLE 5.-Growth characteristics of six late Valencia clones on pummelo hybrid rootstock'.

\begin{tabular}{cllc}
\hline Clone & Height & Width & Canopy volume \\
\hline 2864 & $2.4 \mathrm{ab}^{2}$ & $2.4 \mathrm{~b}$ & $4.6 \mathrm{~b}$ \\
3064 & $2.9 \mathrm{a}$ & $3.3 \mathrm{a}$ & $8.1 \mathrm{a}$ \\
3164 & $2.4 \mathrm{ab}$ & $2.8 \mathrm{ab}$ & $5.2 \mathrm{ab}$ \\
3264 & $2.5 \mathrm{ab}$ & $3.2 \mathrm{a}$ & $6.6 \mathrm{ab}$ \\
3464 & $2.1 \mathrm{~b}$ & $2.8 \mathrm{ab}$ & $5.1 \mathrm{ab}$ \\
4064 & $2.2 \mathrm{~b}$ & $2.4 \mathrm{~b}$ & $3.6 \mathrm{~b}$ \\
\hline
\end{tabular}

'No statistical differences were found with the other rootstocks.

2Values in columns followed by the same letter do not differ significantly at the 0.05 level according to Duncan's multiple range test. 
TABLE 6.-Production characteristics in which statistical differences were found when comparing individual clones with each rootstock'.

\begin{tabular}{|c|c|c|c|c|}
\hline \multirow[b]{3}{*}{ Rootstock } & \multicolumn{2}{|c|}{ Fruits per tree } & \multicolumn{2}{|c|}{ Yield efficiency } \\
\hline & 1985 & 1986 & 1985 & 1986 \\
\hline & $\begin{array}{l}\text { Cleopatra } \\
\text { mandarin }\end{array}$ & $\begin{array}{c}\text { Sour } \\
\text { orange }\end{array}$ & $\begin{array}{l}\text { Sour } \\
\text { orange }\end{array}$ & $\begin{array}{l}\text { Cleopatra } \\
\text { mandarin }\end{array}$ \\
\hline 2864 & $223.6 \mathrm{bc}^{2}$ & $117.8 \mathrm{ab}$ & $43.6 \mathrm{ab}$ & $34.7 \mathrm{ab}$ \\
\hline 3064 & $193.1 \mathrm{c}$ & $95.1 \mathrm{~b}$ & $30.9 \mathrm{~b}$ & $45.2 \mathrm{ab}$ \\
\hline 3164 & $192.5 \mathrm{c}$ & $118.4 \mathrm{ab}$ & $45.6 \mathrm{ab}$ & $25.0 \mathrm{~b}$ \\
\hline 3264 & $328.0 \mathrm{a}$ & $120.6 \mathrm{ab}$ & $43.2 \mathrm{ab}$ & $58.2 \mathrm{a}$ \\
\hline 3464 & $331.5 \mathrm{a}$ & $103.4 \mathrm{~b}$ & $41.1 \mathrm{ab}$ & $39.2 \mathrm{ab}$ \\
\hline 4064 & $300.1 \mathrm{ab}$ & $204.0 \mathrm{a}$ & $48.8 \mathrm{a}$ & $38.8 \mathrm{ab}$ \\
\hline
\end{tabular}

'No statistical differences were found with the other rootstocks.

"Values in columns followed by the same letter do not differ significantly at the 0.05 level according to Duncan's multiple range test.

ferences in tree growth among clones on pummelo hybrid could have resulted from poor compatibility since pummelo is known to be incompatible with other species of citrus. Data on average fruit production per tree indicate that significant differences among clones occurred only in 1986 with Cleopatra mandarin and sour orange rootstocks. Yield efficiency was significantly different in 1985 only between clones 3064 and 4064 grafted on sour orange and between clones 3164 and 3264 grafted on Cleopatra mandarin during the $1986 \mathrm{crop}$.

The study indicates that Cleopatra mandarin is superior to all other rootstocks tested. Trees on this rootstock, regardless of clone, were larger and produced more fruits per tree with high yield efficiency. With the data presented here no particular Valencia clone could be regarded as inferior nor recommended as superior, and all of them should be considered excellent for the region in which they were tested.

\section{LITERATURE CITED}

1. Bitters, W.P., 1968. Valencia orange rootstock trial at South Coast Field Station. Cal. Citrograph; 53:172-74.

2. Conjunto Tecnológico para la Producción de Cítricas, 1975. Publicación \#113. Estación Experimental Agrícola.

3. Estación Experimental Agxícola, 1990. Empresas Agricolas de Puerto Rico: Situación y Perspectivas en 1987-88. Departamento de Economía Agrícola. 
4. Fallani, E., D.R. Rodney and Z. Mousavi, 1990. Growth, yicld and fruit quality of eight lemon cultivars in Arizona. J. Amer. Soc. Hort. Sci. 115:6-8.

5. Pérez López, A. and C.J. Torres, 1984. Growth, yield efficiency and fruit quality of five navel orange clones during four years. J. Agric. Univ. P.R. 68:405-411.

6. Wutscher, H.K. and A.V. Shull, 1972. Performance of 13 citrus cultivars as rootstocks for grapefruit. J. Amer. Soc. Hort. Sci., 97:778-81.

7. - and F.W. Bistline, 1988. Rootstock infuences juice color of Hamlin orange. Hort. Science 23:724-25. 